Article

\title{
Sustainability of State Budgetary Expenses: Tax Compliance of Low-, Middle-, and High-Income Groups-The Evidence from the Czech Republic
}

\author{
Inna Cabelkova
}

Citation: Cabelkova, I. Sustainability of State Budgetary Expenses: Tax Compliance of Low-, Middle-, and High-Income Groups-The Evidence from the Czech Republic. Sustainability 2021, 13, 8966. https://doi.org/ $10.3390 /$ su13168966

Academic Editor: Luis Jesús Belmonte-Ureña

Received: 18 June 2021

Accepted: 27 July 2021

Published: 11 August 2021

Publisher's Note: MDPI stays neutral with regard to jurisdictional claims in published maps and institutional affiliations.

Copyright: (C) 2021 by the author. Licensee MDPI, Basel, Switzerland. This article is an open access article distributed under the terms and conditions of the Creative Commons Attribution (CC BY) license (https:// creativecommons.org/licenses/by/ $4.0 /)$.
Faculty of Economics and Management, Czech University of Life Sciences, 16500 Prague, Czech Republic; cabelkova@pef.czu.cz

\begin{abstract}
In the aftermath of the COVID pandemic, the long-term sustainability of state budgetary expenses is intimately connected to tax compliance. The new solidarity tax is one of the policies designed to help. In the Czech Republic, solidarity tax, introduced in the aftermath of the financial crisis of 2008-2009, is still levied. This paper studies the tax compliance of different income groups in the presence of solidarity tax. Most existing studies suggest declining tax compliance with income, though others found the opposite. This paper argues that the association of tax compliance with income is more complex. This paper assesses tax compliance as related to income in a continuous setting and by comparing income groups employing a large sample from the Czech Republic ( $\mathrm{N}=1811$, $60.6 \%$ female, aged 18-82, $\mathrm{M} \pm \mathrm{SD}: 51.3 \pm 17.2 ; 19.3 \%$ with higher education). Methodologically we rely on ANOVA analyses with post-hoc tests, correlations, and ordinal regressions. We find that the associations of income and tax compliance of linear, quadratic, shift position, and slope were not statistically significant if controlling for age, gender, and education. The ethical acceptability of cheating on tax is the lowest in the middle-income group, presenting $33 \%$ of the sample. The lowest and the highest income group show more ethical flexibility in claiming state benefits if not entitled. The paper presents interesting ideas for policymakers on the tax behavior of different income groups.
\end{abstract}

Keywords: tax compliance; income; survey

\section{Introduction}

In the aftermath of the COVID pandemic, many governments look for additional sources of income to finance the COVID-related holes in their budgets. Higher taxation seems to be one way to go [1,2], though it may slow down economic recovery [3]. A new solidarity personal income tax seems one way to go [4]. In the Czech Republic, a solidarity income tax, introduced in 2013 as a response to the financial crisis of 2008-2009, is still levied. It diverts an additional $7 \%$ of the incomes exceeding 48 times the average annual wage of approx. 5573 EUR monthly (in 2020). This paper studies the tax compliance of income groups in the Czech Republic.

Taxation of high incomes is important for many reasons. First, taxes paid by the most affluent taxpayers are indispensable for the state budget. In absolute numbers, the wealthiest $2.7 \%$ in the United States pay about $51.6 \%$ of the total income taxes [5]. The wealthiest $5.6 \%$ in Germany contributed $43.25 \%$ of the total income taxes [6]. Second, taxation of the rich is less distortionary for the national welfare than taxation of the poor. One dollar paid in taxes rich reduces the total utility of the society to less than one dollar taken from the poor. Next, taxation of the wealthy reduces income inequality and may support economic growth [7] and prevent other socio-economic challenges [8,9]. Tax avoidance by the high earners influences the tax morale of the whole nation, as other groups of people stop seeing the tax system as being fair [10]. The rampant tax avoidance of the rich constitutes one of the economic challenges nowadays [11,12]. Tax compliance of 
the poor is important too. Though the low incomes do not have much to offer in taxes, tax compliance is important psychologically. It may give the poor a sense of participation.

Literature reports positive, negative, or non-existent effects of income on tax compliance (Table 1). It is positive because it is less burdensome to pay taxes for higher incomes if the tax rate is not too high. The low-income groups may be more prone to tax evasion as they have less income $[13,14]$. The effect of income on tax compliance is negative, as the high-incomes may refuse to pay higher taxes if tax progressivity is high (ibid.). Moreover, high incomes face a higher probability of tax audits and fines, which supposedly increase tax compliance [14-16], but can afford better lawyers and tax advisors to help to evade taxes $[10,14]$. A summary of research on the relation of tax compliance to income is presented in Table 1.

Table 1. The relation of tax compliance to income in the literature.

\begin{tabular}{ccc}
\hline Tax Compliance Is Related to Income & Source & Comments \\
Negatively & {$[13,14,17-23]$} & $\begin{array}{c}\text { Allingham and Sandmo [13] also reported a } \\
\text { negative relation with the uncertainty of income } \\
\text { However, Fishlow and Friedman [25] reported } \\
\text { decreasing income compliance for low incomes }\end{array}$ \\
Positively & {$[24-27]$} & \\
\hline
\end{tabular}

Note: The papers presented in the table employ various methodologies based mostly on surveys and experiments. Hofmann et al. [14] present a meta-analysis of the current research.

This paper suggests that the income-tax compliance relationship is significantly more complex, and the linear model may not be the best approximation. The reasons, lifestyles, and worldviews of the rich and poor might be so different that these two groups should not be viewed lying on the one dimension of income, but should be analyzed separately.

Rich people above certain income levels often live in locked residencies with little contact with the outer communities. They do not use public transportation, as they have private drivers. They do not go shopping as they have their shoppers. They send their children to private schools and universities where they meet the other kids alike. They do not need the services of police as they have their bodyguards [10].

Similarly, the poor often live in closed enclaves, sometimes even ghettos. They go shopping to the closest cheap supermarkets; they do not have much money to travel or send their kids to schools that are far away. They communicate with people alike and share their styles of life, values, and behaviors.

The middle-income group seems to present the biggest social, geographical, and labor mobility and eventually relies on the state services the most. Similarly, to the low-income group they send their children to public schools and rely on state-provided health care. Contrary to the low-income group, they are more likely to use the services of state courtsthey are highly dependent on the safety provided by the police, they may benefit more from higher education and with bigger probability of work in the state sector.

This disconnection of the wealthy and poor enhances tax (and other) attitudes substantially different from the other groups in terms of incentives, legal and political possibilities, and social consequences. Wealthy are not likely to be reliant on the services provided by the state, such as health care, education, or police. They have the money for private health care, private schools for their children, or personal bodyguards. Thus, the willingness to pay taxes for the services they do not effectively use in the community they do not effectively belong to is likely to be lower. Their need for the state is different from the poor. They need the state to provide a stable legal environment that effectively and legally protects their wealth. Thus, they might be interested in the existence of the state and in fulfilling its basic functions, but not the social ones. Naturally, they may be more willing (and able) to evade taxes, so vital for the rest of the country. The question arises on how to persuade them to pay. 
Gangl and Torgler [10] identify three main groups of factors related to the tax compliance of the wealthy on macro-, meso-, and micro-levels: Political and economic conditions, social contextual factors, and individual characteristics (Figure 1). On the macro level, political and economic conditions help the wealthy to avoid taxes via tax havens and secrecy jurisdictions, tax exemptions for philanthropic foundations, and special enforcement regimes. Few, if any, of these legal ways to avoid paying taxes are available for less affluent taxpayers. Moreover, affluent people with political power can modify these legal ways to minimize paying taxes. Governments need to be more active to create political and economic conditions that would incline the rich to pay more.

\begin{tabular}{|c|c|c|}
\hline \multicolumn{3}{|c|}{ Tax compliance } \\
\hline The macro-level factors & $\begin{array}{c}\text { The meso-level } \\
\text { factors }\end{array}$ & $\begin{array}{l}\text { The micro-level } \\
\text { factors }\end{array}$ \\
\hline $\begin{array}{l}\text { Political and economic } \\
\text { conditions }\end{array}$ & $\begin{array}{c}\text { Social and contextual } \\
\text { factors }\end{array}$ & $\begin{array}{c}\text { Individual } \\
\text { characteristics }\end{array}$ \\
\hline $\begin{array}{l}\text { - } \text { tax havens and } \\
\text { secrecy jurisdictions, } \\
\text { - tax exemptions for } \\
\text { philanthropic } \\
\text { foundations, } \\
\text { special enforcement } \\
\text { regimes }\end{array}$ & $\begin{array}{l}\text { activities of tax } \\
\text { practitioners and } \\
\text { wealth managers } \\
\text { the social identity } \\
\text { of wealthy }\end{array}$ & $\begin{array}{ll}\text { - } & \text { values } \\
\text { - } & \text { cognitive styles } \\
\text { - } & \text { the ideas on } \\
& \text { fairness } \\
\text { - } & \text { subjective } \\
& \text { wealth } \\
& \text { perceptions }\end{array}$ \\
\hline
\end{tabular}

Figure 1. The factors related to tax compliance of the wealthy. Source: compiled from [10].

On meso-level, social and contextual factors affecting the tax compliance of the wealthy include activities of tax practitioners and wealth managers and the social identity of the wealthy (ibid). Contrary to many less affluent taxpayers, the tax decisions of the wealthy are not made individually, but in a group of the client, tax practitioner, and wealth manager. Therefore, the level of tax compliance is contingent upon the decisions of several people, some of which are paid to increase the wealth of the client. These people need to be worked with to increase the tax compliance of the wealthy.

The social identity of the wealthy includes a comparison of oneself with individuals of similar financial status and practicing increasing social distancing with less affluent members of society (Figure 1). Both trends support similar tax compliance policies for the wealthy that are differentiated from the poor [32]. An inherent competition of the wealthy for more wealth and status reduces the desire to pay taxes [33,34].

On the micro-level, the individual characteristics of the wealthy influence their tax compliance decisions. These individual characteristics include values, cognitive styles, the ideas of fairness, and subjective wealth perceptions [10] (Figure 1). Due to social isolation, the values of the rich are less egalitarian, and, in general, the rich prefer a higher social hierarchy $[35,36]$. Wealthy are also shown to be less fair-minded and prefer efficiency to equality [37]. Moreover, such immoral behavior as cheating, lying, no concern for others, greed, and egoism increases with wealth [38-40]. All these factors are likely to be related to less tax compliance. On the other hand, some wealthy were found to be more prosocial and moral than non-wealthy people [41,42].

The differences in cognitive styles between the wealthy and others are found to concern emotional stability, extraversion, openness, disagreeableness, narcissism, personal freedom, and control (Figure 1, wealthy are found to have higher scores) $[10,43,44]$. The sense of personal freedom and control can be perceived as limited by taxes; thus, reach people are less likely to comply $[10,45]$. 
The other difference between rich and poor concerns is the concept of fairness (Figure 1). Fairness allows for different interpretations. First, fairness means reciprocation of the service or return of the money paid. Naturally, the poor cannot be expected to reciprocate the money they were transferred by the state from the tax revenues acquired from the rich $[46,47]$. Neither the rich can expect adequate service for their tax money as they are less likely to use state systems of health care, school, or police. Therefore, they may perceive that the tax system treats them unfairly $[48,49]$. This holds even more in the environment, where the use of tax money is inefficient. In case tax money is wasted by the politicians or, worse, is stolen by the politicians, no one would want to pay taxes. Having personal experience with the efficiency of investments, the wealthiest people might have more possibilities for the direct comparisons of the efficiency of private and public money. In case efficiency is higher in the private sector, they would be less willing to direct their money to the public one in the form of taxes. On the other hand, in case if their money is perceived to be critical for group success, wealthy people are more likely to feel responsible and cooperate [50].

Finally, subjective wealth perception of the rich as compared to others influences their tax compliance (Figure 1). As with any perception, the idea of whether subjectively a person is rich or poor depends on the benchmark, income group, or the person he is compared to. In case the comparison group is poor, even the average earning person can consider himself wealthy. On the other hand, if the comparison group is rich, even the super-wealthy person can consider himself poor. In the social environment, the attitude on the personal subjective wealth depends on the ingroup one belongs to, which directs us to the social factors of tax compliance. Rich tend to consider other rich as their ingroup. The competition and comparison of wealth status in this group lead to subjective underestimation of the personal wealth as compared to the wealth of the others. The subjective feeling of being "poor" compared to others may diminish the willingness to comply with tax legislation [10,51].

To sum it up, high- and low-income groups of people differ from the middle-income in many other characteristics than the income. It seems reasonable to hypothesize that the division between the groups might be relatively distinct. Similarly, we may hypothesize that the relation of tax compliance and income is not necessarily linear, and the lowand high-income groups might present more similar tax compliance (or non-compliance) compared to middle-income.

The paper aims to study the different types of associations between tax compliance and income employing a large dataset from the Czech Republic $(\mathrm{N}=1811)$. Namely, we aim

1. To test the association of tax compliance and income controlling for gender age and education (linear, quadratic, and change in position and slope of the relationship)

2. To look for the division lines between different income groups that differentiate tax compliance of one group from the other

3. To compare tax compliance of high-, middle-, and low-income groups according to the division lines above

The results show that neither the quadratic relationship between tax compliance and income nor models with and change in position and slope were statistically significant. The most revealing were the models comparing high-, middle- and low-income groups. The middle-income group proved to be the most tax compliant, while the higher- and lower-income groups presented low tax compliance. The results support the idea that the middle group is the most tax compliant one as it benefits from the government services the most.

\section{Materials and Methods}

\subsection{The Data}

The data were collected in 2018 in the project European Value Study (europeanvaluesstudy.eu). One thousand eight hundred eleven respondents from the Czech Republic were asked to fill out the questionnaire voluntarily and anonymously $(\mathrm{N}=1811,60.6 \%$ female, aged 18-82, $\mathrm{M} \pm$ SD: $51.3 \pm 17.2 ; 19.3 \%$ with higher education). The sample 
selection included multilevel sampling. The data were kindly provided by the GESIS data archive for non-commercial purposes.

\subsection{The Measures}

\subsubsection{The Measures of Tax Compliance}

Two proxies of tax compliance were employed, based on the following questions:

"Please tell me for each of the following statements whether the action is always justifiable, never justifiable, or something in between (10 point scale. 1-Never, 10-Always).

- $\quad$ Cheat on taxes when there is an opportunity

- Require state to support one is not entitled to"

The relation of the second proxy to tax compliance is imperfect as state benefits may not be related to taxation only. In the interpretation related to tax compliance, requiring state support may mean requiring tax exemptions or subventions.

As the 10-point scale presented numerous categories with no or few respondents (see Tables A3 and A4 in Appendix A), the number of categories was reduced to 3. To preserve the symmetricity of the scale, the first three and the last three former categories of 10-point scales were united to form the category "action is not justifiable" and "action is justifiable", respectively. The middle category "something in between" included four former categories (Table A1, in Appendix A). A more extensive discussion on the reasons for this reduction is presented in the section The methods.

\subsubsection{The Measures of Personal Income}

The questionnaire did not contain the question for the net personal income per se. The reason is understandable, as some people do not like to report their incomes publicly. The closest proxy was the household total net income, classified in 10 categories, where the upper boundary of the income was $48000 \mathrm{Kc}$ monthly (approx. 2100 USD) and more (see Table A2 in Appendix A). 18\% of the respondents did not answer the question about income and had to be excluded from the study.

The income question was formulated as follows:

"We would like to know which group your household belongs to if you include all the wages, salaries, pensions, and other income you have. All you have to do is enter a letter indicating the group to which your household belongs after tax and other deductions."

The income of the household was then transformed in two ways. First, we assigned to each respondent the average income of each category. Second, we computed income per person by dividing the income of the respondent by the number of persons in the households.

\subsection{The Hypotheses}

Given the overall contradictory results for the relationship between income and tax compliance, various types of mathematical relationships between income and tax compliance were tested. The first and the most straightforward is to compare tax compliance of low-, middle- and high-income groups where one or more of the groups may statistically differ from the rest. Here, the cut-point of income groups are designed based on the previous analysis. Second, to test the linear relationship between tax compliance and income (tax compliance decreases or increases with income). Third, to test the U-shape (quadratic) relationship of tax compliance and income. This relationship implies that highand low-income groups present more (or less) tax compliance comparing to the average income group. However, contrary to the basic comparisons of the groups presented above, we will hot have to set the boundaries between the groups. Finally, the tax compliance may stay the same until a certain income and increase (decrease) after this income either as a shift in position, a shift in slope, or both.

The following main hypotheses are tested: 
Hypothesis 1. Tax compliance differs in high-, middle-, and low-income groups.

Hypothesis 2. Tax compliance is linearly related to income.

Hypothesis 3. Tax compliance is quadratically related to income.

Hypothesis 4. There is a shift in position and/or slope in relation to tax compliance and income.

\subsection{The Methods}

\subsubsection{Comparisons of Tax Compliance of Income Groups (Hypothesis 1)}

To find cut-off points for income groups, we compared the differences in tax compliance of the first $10 \%$ quantile vs. others, $20 \%$ quantile vs. others, $30 \%$ quantile vs. others, etc., via one-way ANOVA analysis. The first statistically significant cut-off point was employed to differentiate the income groups of high- and middle-income. The cut-off point for the low-income group was chosen symmetrically for the high-income group. As a result, the whole sample was divided into three, approximately equal, groups. The tax compliance of these income groups was compared via ANOVAs with post-hoc test. The Levene test for variance difference was chosen to compare the variances.

This method, though intuitive, has substantial limitations. As the lack of statistical significance does not mean that the variables do not differ (it just means that we do not know whether they are different), it may well happen that the difference between the $\mathrm{n}^{\text {th }}$ decile and the rest occurred in higher income deciles than we can statistically prove. Besides, as the income level of the highest decile in the sample is still relatively low (48,000 CZK per month and more), the method is not likely to discover the non-linearity in the tax-compliance-income relationship present in the most wealthy part of the population. Similarly, applying a statistical test with 5\% significance several times means the lower significance of the conjoint results.

2.4.2. The Association between Income and Tax Compliance Proxies Controlling for Age, Gender, and Education (Hypotheses 2-4)

Two methods were considered. The first, and the most obvious one, is to apply linear regression analysis to original, non-transformed data of both the tax compliance proxies and the income controlling for socio-demographic data. The tax compliance proxies, measured originally on 10-point scales, would then been used as dependent variables consecutively. However, the result of the linear regression is highly dependent on enough observations of all the categories of tax compliance proxies and income. In our case, the three upper categories of tax compliance proxies presented 6 to 30 observations (see Tables A3 and A4 in Appendix A), which makes the representativity of the opinions of these people highly unreliable and increases the probability of large heteroscedasticity of statistical estimations.

The other method implied reduction of the number of categories of tax compliance proxies and using ordinal regression analysis. This method was chosen. The number of categories was reduced to three, according to Table A1 in Appendix A. Though the obvious reduction meant merging the categories with the least numbers of observations only (categories 7-10 in Tables A3 and A4 in Appendix A), this would make the resulting scale non-symmetrical with respect to the justifiability of cheating on tax. We wanted to maintain the symmetricity of the scale; therefore, we reduced the number of categories symmetrically from both sides (merging exactly the same number of categories of respondents for whom cheating on tax was justifiable to different degrees and unjustifiable for different degrees). The resulting symmetricity will make interpretation easier.

A set of ordinal regression analyses was conducted, where we control for age, education, and gender (Formulas (1)-(5)). 
Tax compliance $=$ logit $(\mathrm{a} 0+\mathrm{a} 1$ Income + a2 Age + a3 People + a4 Sex + a5 Education + e)

Tax compliance $=$ logit $(\mathrm{a} 0+\mathrm{a} 1$ Income $+\mathrm{a} 2$ Income $2+\mathrm{a} 3$ Age $+\mathrm{a} 4$ People $+\mathrm{a} 5$ Sex + a6 Education $+\mathrm{e})$

Tax compliance $=$ logit $\left(\mathrm{a} 0+\mathrm{a} 1\right.$ Income + a1 Income ${ }^{*}$ Dummy1 + a2 Age + a3 People + a4 Sex + a5 Education + e $)$

Tax compliance $=\operatorname{logit}(\mathrm{a} 0+\mathrm{a} 1$ Income + Dummy $1+\mathrm{a} 1$ Income Dummy1

$$
+ \text { a2 Age + a3 People + a4 Sex + a5 Education + e) }
$$

Tax compliance $=\operatorname{logit}(\mathrm{a} 0+\mathrm{a} 1$ Income + Dummy $1+\mathrm{a} 2$ Age $+\mathrm{a} 3$ People $+\mathrm{a} 4$ Sex $+\mathrm{a} 5$ Education $+\mathrm{e})$

where:

Tax compliance - the tax compliance proxies: Justifiability of cheating on tax and claiming state benefits if not entitles consecutively.

Income-income proxies: Income of the household, income per person of the household consecutively

People-number of people in the household. The variable is employed only in the case if income is measured as the income of the household (not personal income)

Dummy 1-dummy presenting the cut-off point of various income groups (10\% quantile vs. others, $20 \%$ quantile vs. others, $30 \%$ quantile vs. others, etc.)

Age, Sex, Education-age, sex, education dummies of the respondents.

Models (2-5) did not present the improvement of the results achieved in the model (1). None of the quadratic effects, various combinations of dummy variables were statistically significant. We do not present the results of the models of (2-5), due to the conciseness of the paper. We report correlations for the main variables.

\section{Results}

\subsection{The Cut-Off Point for the High-Income Group}

The results presented in the introductory sections suggest, that the rich group of people might have lower tax compliance than the rest, due to various value, behavioral differences, and the difference in the lifestyles. However, no evidence exists as to how widely or narrowly the group should be defined. Should it represent wealthiest $10 \%$, or $20 \%$, or $30 \%$ ? In this paper, we take advantage of the representative sample and compare tax compliance of the highest income groups versus the others. First, we compare wealthiest $10 \%$ versus the others, then $20 \%$, etc.

The results of ANOVA analyses of different income groups defined according to the total household income and income per person in the household are presented in Tables 2 and 3. For this analysis, we employ the original (not-transformed) variables of claiming state benefits that ranged from 1 to 10.

Table 2. Comparing tax compliance of household income groups (income of the household). The results of ANOVA analysis.

\begin{tabular}{|c|c|c|c|c|c|c|}
\hline \multirow[t]{2}{*}{$\begin{array}{c}\text { The Income Group (Deciles on Total } \\
\text { Household Income) }\end{array}$} & \multirow{2}{*}{$\begin{array}{c}\text { Monthly Household } \\
\text { Income above }\end{array}$} & \multicolumn{2}{|c|}{$\begin{array}{c}\text { Claiming } \\
\text { State Benefits }\end{array}$} & \multicolumn{3}{|c|}{ Cheating on Tax } \\
\hline & & Sig. & $\mathbf{N}$ & Mean Difference & Sig. & $\mathbf{N}$ \\
\hline 10th decile vs. others & $48,000(2086)$ & 0.267 & 1373 & & 0.104 & 1382 \\
\hline 9th and 10th deciles vs. others & $40,000(1739)$ & 0.553 & 1373 & & 0.165 & 1382 \\
\hline 8th, 9th, and 10th deciles vs. others & $36,000(1565)$ & 0.190 & 1373 & $0.240^{b}$ & 0.036 & 1382 \\
\hline 7th, 8th, 9th, and 10th deciles vs. others & $31,000(1347)$ & 0.362 & 1373 & $0.260^{b}$ & 0.015 & 1382 \\
\hline 6 th, 7 th, 8 th, 9 th, and 10 th deciles vs. others & $27,000(1173)$ & 0.369 & 1373 & $0.200^{\mathrm{a}}$ & 0.057 & 1382 \\
\hline
\end{tabular}

Source: Own computations for the data EVS, GESIS, 2018. ${ }^{a}$ The result is significant at a $10 \%$ level. ${ }^{\mathrm{b}}$ The result is significant on a $5 \%$ level. 
Table 3. Comparing tax compliance of income groups (income per person). The results ANOVA analysis.

\begin{tabular}{|c|c|c|c|c|c|c|}
\hline \multirow[t]{2}{*}{ The Income Group (Deciles on Income Per Person) } & \multicolumn{3}{|c|}{ Claiming State Benefits } & \multicolumn{3}{|c|}{ Cheating on Tax } \\
\hline & Mean Difference & Sig. & $\mathbf{N}$ & Mean Difference & Sig. & $\mathbf{N}$ \\
\hline 10th decile vs. others & -0.170 & 0.338 & 1353 & 0.210 & 0.192 & 1362 \\
\hline 9th and 10th deciles vs. others & -0.030 & 0.820 & 1353 & 0.210 & 0.116 & 1362 \\
\hline 8th-10th deciles vs. others & 0.120 & 0.295 & 1353 & $0.238^{b}$ & 0.036 & 1362 \\
\hline 7th-10th deciles vs. others & -0.080 & 0.515 & 1353 & -0.010 & 0.889 & 1362 \\
\hline 6th-10th deciles vs. others & -0.150 & 0.188 & 1353 & -0.060 & 0.538 & 1362 \\
\hline
\end{tabular}

Source: Own computations. ${ }^{\mathrm{b}}$ The result is significant on a $5 \%$ level.

Tables 2 and 3 show that the high-income group of the respondents should not be defined too narrowly as the 9th and 10th deciles of the respondents did not prove to be statistically different from the rest of the population. However, the group defined as 8th-10th decile proved to be different from the rest of the respondents in justifiability of cheating in tax. This holds for both proxies of income per person and total household income. So, this boundary that differentiates approximately $30 \%$ of the sample with the highest incomes will be used in further analysis. Symmetrically we will define the group of the respondents with the lowest incomes as approximately $30 \%$ of the sample with the lowest incomes.

\subsection{The Differences in Tax Compliance of Low-, Middle-, and High-Income Groups. One-Way} ANOVAs and Post-Hoc Tests

Figure 2 presents averages and $95 \%$ confidence intervals for the tax compliance proxies three equal income groups defined as approximately $30 \%$ of the sample each.
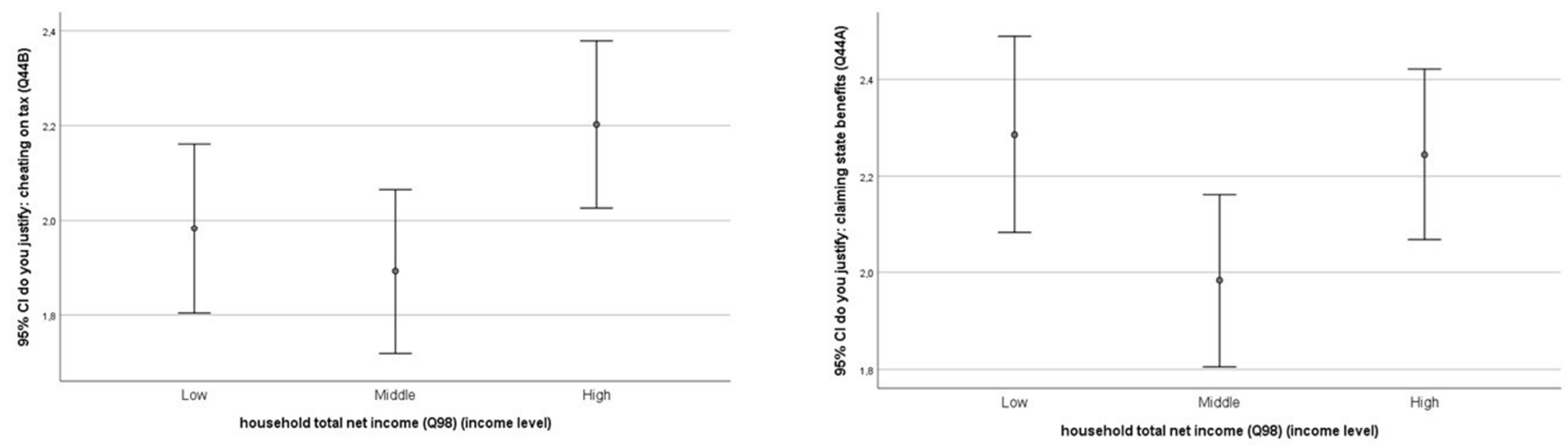

Figure 2. Means and confidence intervals for cheating on tax and claiming state benefits depending on household net income (approx. 33\% quantiles low, middle, high). Source: Own computations from the data from EVS, GESIS, (2018).

From the first glance, it seems that high-earning respondents present more tolerance for cheating on tax and claiming state benefits if not eligible. Table 4 presents the results of one-way ANOVA and including the LSD post-hoc tests to compare the tax compliance of income groups.

Table 4 shows that middle-income respondents are less inclined to justify claiming state benefits if not entitled compared to low- and high-income respondents. Similarly, high-income respondents are more willing to justify cheating on tax than two other groups of respondents.

The comparisons of tax compliance of the income groups defined according to income per person are presented in Figure 3 and Table 5. Figure 3 presents means and confidence intervals for tax compliance of low-, middle-, and high-income groups. Table 5 presents the results of ANOVA analysis with post-hoc tests comparing tax compliance of low-, middle-, and high-income groups. 
Table 4. Comparing average tax compliance of high-, middle-, and low-income groups. Results of ANOVA and post-hoc tests (LSD).

\begin{tabular}{|c|c|c|c|c|c|c|c|}
\hline $\begin{array}{c}\text { Tax Compliance Proxy: } \\
\text { Do You Justify }\end{array}$ & $\begin{array}{l}\text { (I) Household } \\
\text { Total Net Income }\end{array}$ & $\begin{array}{l}\text { (J) Household } \\
\text { Total Net Income }\end{array}$ & $\begin{array}{c}\text { Mean } \\
\text { Difference (I-J) }\end{array}$ & $\begin{array}{l}\text { Std. } \\
\text { Error }\end{array}$ & Sig. & $\begin{array}{l}\text { Sig. of } \\
\text { ANOVA }\end{array}$ & $\mathbf{N}$ \\
\hline \multirow{6}{*}{ Claiming state benefits } & \multirow{2}{*}{ Low } & Middle & $0.302^{b}$ & 0.137 & 0.028 & \multirow[t]{6}{*}{$0.059^{\mathrm{a}}$} & \multirow[t]{6}{*}{1373} \\
\hline & & High & 0.041 & 0.132 & 0.755 & & \\
\hline & \multirow{2}{*}{ Middle } & Low & $-0.302^{b}$ & 0.137 & 0.028 & & \\
\hline & & High & $-0.261^{\mathrm{a}}$ & 0.135 & 0.053 & & \\
\hline & \multirow{2}{*}{ High } & Low & -0.041 & 0.132 & 0.755 & & \\
\hline & & Middle & $0.261^{\mathrm{a}}$ & 0.135 & 0.053 & & \\
\hline \multirow{6}{*}{ Cheating on tax } & \multirow{2}{*}{ Low } & Middle & 0.090 & 0.130 & 0.487 & \multirow[t]{6}{*}{$0.040^{\mathrm{b}}$} & \multirow[t]{6}{*}{1382} \\
\hline & & High & $-0.220^{\mathrm{a}}$ & 0.125 & 0.078 & & \\
\hline & \multirow{2}{*}{ Middle } & Low & -0.090 & 0.130 & 0.487 & & \\
\hline & & High & $-0.310^{b}$ & 0.127 & 0.015 & & \\
\hline & \multirow{2}{*}{ High } & Low & $0.220^{\mathrm{a}}$ & 0.125 & 0.078 & & \\
\hline & & Middle & $0.310^{\mathrm{b}}$ & 0.127 & 0.015 & & \\
\hline
\end{tabular}

Source: Own computations from the data EVS, GESIS, 2018. ${ }^{\mathrm{a}}$ The result is significant on $10 \%$ level. ${ }^{\mathrm{b}}$ The result is significant on a $5 \%$ level.
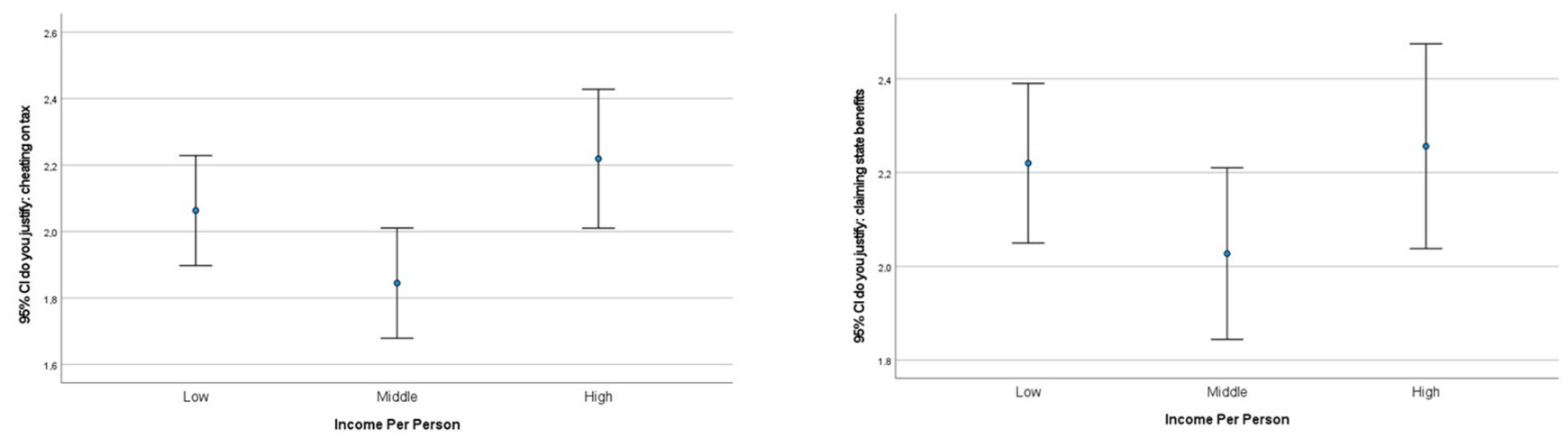

Figure 3. Means and confidence intervals for cheating on tax and claiming state benefits depending on household net income per person (approx. 33\% quantiles low, middle, high). Source: Own computations from the data from EVS, (europeanvaluesstudy.eu).

Table 5. Comparing average tax compliance of high-, middle-, and low-income groups according to household net income per person. Results of ANOVA and post-hoc tests (LSD).

\begin{tabular}{|c|c|c|c|c|c|c|c|}
\hline $\begin{array}{c}\text { Tax Compliance Proxies: } \\
\text { Do You Justify: }\end{array}$ & $\begin{array}{l}\text { (I) Income Per } \\
\text { Person }\end{array}$ & $\begin{array}{l}\text { (J) Income Per } \\
\text { Person }\end{array}$ & $\begin{array}{c}\text { Mean Difference } \\
\text { (I-J) }\end{array}$ & $\begin{array}{l}\text { Std. } \\
\text { Error }\end{array}$ & Sig. & $\begin{array}{l}\text { Sig. of } \\
\text { ANOVA }\end{array}$ & $\mathbf{N}$ \\
\hline \multirow{6}{*}{ Cheating on tax } & \multirow{2}{*}{ Low } & Middle & $0.218^{a}$ & 0.123 & 0.076 & \multirow[t]{6}{*}{$0.021^{b}$} & \multirow[t]{6}{*}{1363} \\
\hline & & High & -0.156 & 0.130 & 0.232 & & \\
\hline & \multirow{2}{*}{ Middle } & Low & $-0.218^{a}$ & 0.123 & 0.076 & & \\
\hline & & High & $-0.374^{c}$ & 0.136 & 0.006 & & \\
\hline & \multirow{2}{*}{ High } & Low & 0.156 & 0.130 & 0.232 & & \\
\hline & & Middle & $0.374^{\mathrm{c}}$ & 0.136 & 0.006 & & \\
\hline \multirow{6}{*}{$\begin{array}{l}\text { Claiming state benefits if } \\
\text { not entitled }\end{array}$} & \multirow{2}{*}{ Low } & Middle & 0.193 & 0.130 & 0.138 & \multirow[t]{6}{*}{0.206} & \multirow[t]{6}{*}{1354} \\
\hline & & High & -0.036 & 0.137 & 0.792 & & \\
\hline & \multirow{2}{*}{ Middle } & Low & -0.193 & 0.13 & 0.138 & & \\
\hline & & High & -0.229 & 0.144 & 0.112 & & \\
\hline & \multirow{2}{*}{ High } & Low & 0.036 & 0.137 & 0.792 & & \\
\hline & & Middle & 0.229 & 0.144 & 0.112 & & \\
\hline
\end{tabular}

Source: Own computations from the data EVS, GESIS, 2018. ${ }^{a}$ The result is significant on $10 \%$ level. ${ }^{\mathrm{b}}$ The result is significant on a $5 \%$ level.

${ }^{\mathrm{c}}$ The result is significant at $1 \%$ level. 
Table 5 follows that the middle-income group is less willing to justify cheating on tax than the high- and low-income groups. The group differences in claiming state benefits if not entitled were not significantly different.

\subsection{Tax Compliance and Income. The Results of Ordinal Regressions}

We conducted a set of ordinal regression analyses, where we control for age, education, and gender, testing different functions of income as related to tax compliance (Formulas (1)-(5)). None of the added quadratic or dummy related terms were statistically significant in the models with the quadratic term (Formula (2)) or with different types of change in position or slope of income as related to tax compliance. To make the paper concise, we report only the results of the first simples model presented by Formula (1). To assess the difference between the linear and discrete functions of income, we compute both the model, where the income is included as a continuous variable, and as a group of incomes-low-, middle-, and high-income groups. The results are presented in Table 6. The first two regressions (for cheating on tax and claiming state benefits as dependent variables subsequently) study the association between tax compliance and household income measured in three income groups (low-, middle-, high-) where the high-income group was used as a reference variable. The second two regressions study the association between the tax compliance proxies and income per person. The last two regression analyses present the association between tax compliance proxies and total household income.

Table 6. Results of ordinal regression analysis predicting justifiability of cheating on tax and claiming state benefits if not entitled.

\begin{tabular}{|c|c|c|c|c|c|c|c|c|c|c|c|c|}
\hline & \multicolumn{2}{|c|}{ Cheating on Tax } & \multicolumn{2}{|c|}{$\begin{array}{l}\text { Claiming State } \\
\text { Benefits }\end{array}$} & \multicolumn{2}{|c|}{ Cheating on Tax } & \multicolumn{2}{|c|}{$\begin{array}{l}\text { Claiming State } \\
\text { Benefits }\end{array}$} & \multicolumn{2}{|c|}{ Cheating on Tax } & \multicolumn{2}{|c|}{$\begin{array}{l}\text { Claiming State } \\
\text { Benefits }\end{array}$} \\
\hline & Estimate & Sig. & Estimate & Sig. & Estimate & Sig. & Estimate & Sig. & Estimate & Sig. & Estimate & Sig. \\
\hline Threshold $=1$ & 0.270 & 0.493 & 0.080 & 0.834 & $0.733^{b}$ & 0.021 & -0.166 & 0.588 & 0.189 & 0.646 & $-0.711^{\mathrm{a}}$ & 0.071 \\
\hline Threshold $=2$ & $2.053^{c}$ & 0.000 & $2.017^{c}$ & 0.000 & $2.515^{\mathrm{c}}$ & 0.000 & $1.759^{c}$ & 0.000 & $1.971^{\mathrm{c}}$ & 0.000 & $1.220^{c}$ & 0.003 \\
\hline \multicolumn{13}{|l|}{ Income proxies } \\
\hline household total net income $=$ low & 0.114 & 0.601 & $0.622^{c}$ & 0.003 & & & & & & & & \\
\hline household total net income $=$ middle & -0.122 & 0.544 & 0.017 & 0.930 & & & & & & & & \\
\hline household total net income & & & & & & & & & -0.012 & 0.907 & $-0.256^{\mathrm{b}}$ & 0.013 \\
\hline $\begin{array}{c}\text { Income per person } \\
\text { Sociodemographic variables }\end{array}$ & & & & & 0.192 & 0.262 & -0.205 & 0.253 & & & & \\
\hline number of people in a household & -0.068 & 0.369 & 0.015 & 0.838 & & & & & -0.083 & 0.268 & -0.004 & 0.951 \\
\hline age & $-0.028^{c}$ & 0.000 & $-0.040^{c}$ & 0.000 & $-0.026^{c}$ & 0.000 & $-0.036^{c}$ & 0.000 & $-0.028^{c}$ & 0.000 & $-0.040^{\mathrm{c}}$ & 0.000 \\
\hline sex $=$ male & 0.173 & 0.270 & 0.142 & 0.352 & 0.143 & 0.361 & 0.128 & 0.399 & 0.163 & 0.298 & 0.129 & 0.394 \\
\hline education = lower & -0.179 & 0.595 & 0.218 & 0.475 & -0.060 & 0.859 & 0.338 & 0.263 & -0.153 & 0.653 & 0.211 & 0.492 \\
\hline education $=$ medium & 0.083 & 0.675 & 0.198 & 0.313 & 0.134 & 0.499 & 0.214 & 0.274 & 0.077 & 0.698 & 0.161 & 0.415 \\
\hline \multicolumn{13}{|l|}{ Pseudo R-square } \\
\hline Cox and Snell & 0.028 & & 0.063 & & 0.027 & & 0.055 & & 0.027 & & 0.059 & \\
\hline Nagelkerke & 0.044 & & 0.095 & & 0.042 & & 0.082 & & 0.043 & & 0.089 & \\
\hline McFadden & 0.028 & & 0.059 & & 0.027 & & 0.051 & & 0.027 & & 0.055 & \\
\hline Sig. & 0.000 & & 0.000 & & & 0.000 & & 0.000 & & 0.000 & & 0.000 \\
\hline $\mathrm{N}$ & 1811 & & 1811 & & 1338 & & 1327 & & & 1338 & & 1327 \\
\hline
\end{tabular}

Source: Own computations on the data EVS, GESIS, 2018. ${ }^{\text {a }}$ The result is significant on a $10 \%$ level. ${ }^{b}$ The result is significant on $5 \%$ level, ${ }^{c}$ The result is significant on $1 \%$ level. Reference variables: Total household income $=$ high, sex of the respondent-female, education-higher.

The results presented in Table 6 tested different types of relationships between tax compliance and income. The first two regressions measured income in three income groups-(high-, middle-, and low-income). Opposite to ANOVA analysis with post-hoc tests, that compared tax compliance of three income groups in all the possible couples, the ordinal regression analysis compares two income groups (low- and middle-) to the group chosen as reference variable (high-income). This allows to test the difference in tax compliance of high-income group versus others (similar to ANOVAs in Tables 2 and 3) controlling for sociodemographic variables, but does not enable to compare the tax compliance of lowand middle-income groups (as in ANOVAs in Tables 4 and 5).

The results suggest that cheating on tax in low- and middle- income groups did not prove to be different from the high-income group when controlling for gender, age, and education. 
Thus, we may suggest that the differences in cheating on tax from the high-income group versus others may be due to the different level of age or education, or different gender.

However, the low-income group justified claiming state benefits if not entitled to more than the higher income group. The explanation is rather obvious, as the low-income group may receive social security compensations and may abuse the state system.

The second two regression analyses studied the association of tax compliance and income per person controlling for age, gender, and education. The latter did not show to be related to any of the proxies of tax compliance.

The last two regressions studied the linear association between household income and tax compliance controlling for age, gender, and education. The household income was not related to cheating on tax. The justifiability of claiming state benefits if not entitled is negatively related to income. The result is understandable as the lower is the income, the more state social security benefits the person is entitled to.

The age of the respondents proved to be the single most significant variable predicting the tax compliance proxies. The higher the respondents' age, the less they believe that cheating on tax and claiming state benefits if not entitled are justifiable. Gender and education were not related to tax compliance.

\section{Discussion}

This paper studied the associations between tax compliance and income. We used two proxies for tax compliance- the justifiability or cheating on tax and claiming state benefits if not entitled. We used three proxies for income-income group (low-, middle-, high-), income of household, and income of household per person. We studied the associations of linear, and non-linear types.

One of the most important parts of the literature on tax compliance relates to the tax compliance of the high-income groups, as their contributions to the state budgets are higher comparing to low incomes (see [10]). The results of the one-factorial ANOVA analysis presented in this paper suggest that high-income respondents are more willing to justify cheating on tax compared to others. Indeed, the people who contribute the most are the most willing to evade taxes [14].

When in the ordinal regression analysis controlling for age, gender and education, one more interesting association appeared-a negative relationship between income and the justifiability of claiming state benefits. Naturally, this may reflect not only the attitude to taxation, but also the frequency one enjoys other social security benefits than those related to taxation.

These results support several conclusions presented in the introductory part. First, the low-income groups may be more prone to tax evasion as they have less income to pay taxes from $[13,14]$. Second, tax compliance may be negatively related to income because, in case of higher progressivity of taxes, the high-income groups may refuse to pay a higher proportion of the income, and if legislatively adopted, but not enforced enough, will do their best to evade taxes (ibid.). Third, higher-income groups face a more significant probability of tax audits and fines, which supposedly increase tax compliance [15,16], but can afford better lawyers and tax advisors to help to evade taxes [10].

The higher reported honesty of the middle-income group is in line with the idea that middle-income is the most formative for the state institutions in democratic environments [52]. The low-income people will not comply with the state regulations, since they have little to lose, whereas the higher income group would not comply, because they are not that dependent on state institutions, and they have more means to disobey. The middle class was also shown to have the greatest effect on policy institutions and quality of governance [53] and on levels of corruption and institutional quality [54,55].

Out of all analyses presented above, it follows that middle-income respondents are less inclined to justify claiming state benefits if not entitled compared to low- and high-income respondents. This result is similar to the work by the authors of [56], who suggested as a Utype relationship between income and tax compliance. However, when testing the U-type relationship directly in regression analysis, the outcome was not statistically significant. 
This result might be caused by controlling for sociodemographic variables, from which age proved to be extremely significant in all the regressions. The significance of age in the post-communist Czech Republic makes us hypothesize on whether the communist experience of older respondents did not affect the tax compliance decisions more than income itself. On the other hand, the significance of age was well reported in other studies (for the meta-analysis of the literature, see [14]); thus, there might be other reasons

\section{Conclusions}

The sustainability of government budgets is impossible without tax compliance. Taxes are indispensable for the smooth functioning of modern societies. Tax schedules are often designed according to income. The classical literature on the willingness of income groups to pay taxes presents two major arguments: The low incomes prefer to reduce their taxes as they do not possess the funds to pay, and the high incomes with to reduce their tax duties as they consider them too high [14]. This paper studies the association between tax compliance and income. It claims that the motivations of different income groups for tax compliance are significantly different.

The lifestyles, values, and types of activities of low-, middle-, and high-income people differ substantially [10]. Super rich live in closed areas; they do not use public transportation, do not send their children to public schools, do not shop in local supermarkets. Consequently, the overall connection of the high-income group to the society is limited, and the values are more influenced by the members of this ingroup (ibid.). The disconnection of the rich from the rest may lead to even lower tax compliance than that caused just by the sole higher taxation of the rich.

Similarly, the low-income group may be disconnected too. They also may live in closed ghettos, shop in the cheapest local supermarkets; some of them may live primarily from security benefits and have financial troubles to send their kid to school after the compulsory education. The taxation attitudes are also formed on substantially different sets of habits, values, and experiences. Thus, we suggest that tax compliance should not be taken as a continuous function of incomes, but rather the three income groups should be studied separately.

This paper studied the association between tax compliance and income. Researches often speak of rich and poor, though how rich should be rich and how poor should be poor is rarely defined. Moreover, it differs depending on the point of view and subject analyzed. Relevant to tax compliance, we attempted to find the division lines of the high-, middle-, and low-income groups and compare subjective tax compliance of these groups on a representative sample from the Czech Republic. We found that in the Czech Republic, the high-income group of respondents can be defined as approximately the $30 \%$ quantile of incomes. In the one-factor ANOVA analysis, the low- and high-income groups were more similar in tax compliance compared to the middle-income group. Both groups presented lower compliance.

While the one-factors analysis may be important for policymakers when designing the tax schedules, from the researcher's perspective, we need to study the third factors that might contribute to the association between tax compliance and income. In the ordinal regression analysis, we controlled for age, gender, and education. The results of ordinal regression analysis showed the difference between the low and high-income groups in the proxy of claiming state benefits if not entitled, but not the difference between middle and high-income groups. Similarly, the results of the ordinal analysis also presented negative relation of claiming state benefits if not entitles with income (controlling for age, gender, and education). Surprisingly, besides income, age proved to be the most significant factor related to tax compliance. The mediation effect of age on the relation of tax compliance and income may be the next suggestion for analysis.

The results of this paper can be interesting for the researchers and the policymakers.

Funding: This research received no external funding.

Institutional Review Board Statement: The study was conducted according to the guidelines of the Declaration of Helsinki, and approved by the Institutional Review Board (or Ethics Committee) of Czech University of Life Sciences (protocol code DTF1512/2020, 15.12.2020). 
Informed Consent Statement: Informed consent was obtained from all subjects involved in the study.

Data Availability Statement: The data are available at https:/ / europeanvaluesstudy.eu/ (accessed on 18 June 2021).

Conflicts of Interest: The author declares no conflict of interest.

\section{Appendix A}

Table A1. The distribution of the respondents on the proxies for tax compliance.

\begin{tabular}{cccc}
\hline New Categories & Former Categories & Cheating on Taxes, $\%$ & Claiming State Benefits, $\%$ \\
\hline Action is not justifiable & $1,2,3$ & 83.0 & 79.5 \\
Something in between & $4,5,6,7$ & 11.7 & 14.2 \\
Action is justifiable & $8,9,10$ & 3.0 & 3.3 \\
Missing & & 2.4 & 3.0 \\
Total, $\%$ & 100 & 100 \\
N & & 1811 & 1811 \\
\hline
\end{tabular}

Source: Computations by the author from the data (europeanvaluesstudy.eu).

Table A2. Categories of monthly net household income.

\begin{tabular}{ccccc}
\hline Category No. & Category Letter, Decile & Range, CZK & No. of the Respondents & Valid Percent \\
\hline 1 & A-1st decile & Less than 12,000 & 137 & 9.7 \\
2 & B-2nd decile & $12,001-16,000$ & 196 & 13.9 \\
3 & C-3rd decile & $16,001-20,000$ & 133 & 9.4 \\
4 & D-4th decile & $20,001-24,000$ & 181 & 12.8 \\
5 & E-5th decile & $24,001-27,000$ & 129 & 9.1 \\
6 & F-6th decile & $27,001-31,000$ & 111 & 7.9 \\
7 & G-7th decile & $31,001-36,000$ & 106 & 7.5 \\
8 & H-8th decile & $36,001-40,000$ & 140 & 9.9 \\
9 & I-9th decile & $40,001-48,000$ & 148 & 10.5 \\
\hline
\end{tabular}

Note: The categories roughly correspond to deciles in data. The wording of the question "We would like to know which group your household belongs to if you include all the wages, salaries, pensions and other income you have. All you have to do is enter a letter indicating the group to which your household belongs after tax and other deductions" (europeanvaluesstudy.eu). The total number of valid observations is 1410, which represents 77.9 of the data. Valid percent represents the percent of these valid observations. Source: Aggregated by the author from data collected in 2018 in the project European Value Study (europeanvaluesstudy.eu).

Table A3. Crosstabulation claiming state benefits proxy versus income groups (count).

\begin{tabular}{|c|c|c|c|c|c|c|c|c|c|c|c|}
\hline \multirow{2}{*}{$\begin{array}{c}\text { Tax Benefits } \\
\text { Justification }^{a}\end{array}$} & \multicolumn{10}{|c|}{ Households Total Net Income } & \multirow[b]{2}{*}{ Total } \\
\hline & $\begin{array}{c}\text { 1st } \\
\text { Decile }\end{array}$ & $\begin{array}{c}\text { 2nd } \\
\text { Decile }\end{array}$ & $\begin{array}{c}\text { 3rd } \\
\text { Decile }\end{array}$ & $\begin{array}{c}\text { 4th } \\
\text { Decile }\end{array}$ & $\begin{array}{c}5 \text { th } \\
\text { Decile }\end{array}$ & $\begin{array}{c}\text { 6th } \\
\text { Decile }\end{array}$ & $\begin{array}{c}\text { 7th } \\
\text { Decile }\end{array}$ & $\begin{array}{c}\text { 8th } \\
\text { Decile }\end{array}$ & $\begin{array}{c}\text { 9th } \\
\text { Decile }\end{array}$ & $\begin{array}{c}\text { 10th } \\
\text { Decile }\end{array}$ & \\
\hline Never 1 & 76 & 135 & 73 & 119 & 90 & 70 & 69 & 55 & 87 & 80 & 854 \\
\hline 2 & 18 & 18 & 16 & 24 & 13 & 20 & 14 & 14 & 14 & 23 & 174 \\
\hline 3 & 7 & 8 & 8 & 9 & 6 & 10 & 11 & 11 & 12 & 11 & 93 \\
\hline 4 & 10 & 3 & 3 & 7 & 1 & 4 & 1 & 6 & 8 & 2 & 45 \\
\hline 5 & 16 & 13 & 10 & 11 & 7 & 6 & 1 & 11 & 7 & 13 & 95 \\
\hline 6 & 1 & 6 & 5 & 4 & 2 & 3 & 8 & 3 & 2 & 2 & 36 \\
\hline 7 & 1 & 1 & 4 & 1 & 3 & 3 & 3 & 2 & 5 & 5 & 28 \\
\hline 8 & 2 & 3 & 3 & 0 & 2 & 1 & 1 & 1 & 1 & 6 & 20 \\
\hline 9 & 0 & 3 & 1 & 0 & 1 & 1 & 0 & 0 & 0 & 0 & 6 \\
\hline Always 10 & 4 & 3 & 4 & 2 & 2 & 2 & 1 & 2 & 2 & 1 & 23 \\
\hline Total & 135 & 193 & 127 & 177 & 127 & 120 & 109 & 105 & 138 & 143 & 1374 \\
\hline
\end{tabular}

a Do you justify: Claiming state benefits if not entitled (1—never, 10—always). Source: computations of the author. 
Table A4. Crosstabulation cheating on tax proxy versus income groups (count).

\begin{tabular}{|c|c|c|c|c|c|c|c|c|c|c|c|}
\hline \multirow{2}{*}{$\begin{array}{c}\text { Cheating on Tax } \\
\text { Justification }^{\mathrm{a}}\end{array}$} & \multicolumn{10}{|c|}{ Households Total Net Income } & \multirow[b]{2}{*}{ Total } \\
\hline & $\begin{array}{c}\text { 1st } \\
\text { Decile }\end{array}$ & $\begin{array}{c}\text { 2nd } \\
\text { Decile }\end{array}$ & $\begin{array}{c}\text { 3rd } \\
\text { Decile }\end{array}$ & $\begin{array}{c}\text { 4th } \\
\text { Decile }\end{array}$ & $\begin{array}{c}5 \text { th } \\
\text { Decile }\end{array}$ & $\begin{array}{c}\text { 6th } \\
\text { Decile }\end{array}$ & $\begin{array}{c}7 \text { th } \\
\text { Decile }\end{array}$ & $\begin{array}{c}\text { 8th } \\
\text { Decile }\end{array}$ & $\begin{array}{c}\text { 9th } \\
\text { Decile }\end{array}$ & $\begin{array}{c}\text { 10th } \\
\text { Decile }\end{array}$ & \\
\hline never & 89 & 141 & 77 & 120 & 90 & 84 & 65 & 61 & 92 & 80 & 899 \\
\hline 2 & 22 & 20 & 16 & 20 & 17 & 16 & 16 & 14 & 13 & 24 & 178 \\
\hline 3 & 8 & 4 & 9 & 14 & 3 & 6 & 11 & 10 & 10 & 16 & 91 \\
\hline 4 & 5 & 6 & 9 & 4 & 4 & 7 & 1 & 5 & 4 & 5 & 50 \\
\hline 5 & 8 & 9 & 7 & 8 & 6 & 2 & 4 & 4 & 12 & 8 & 68 \\
\hline 6 & 1 & 3 & 2 & 3 & 3 & 2 & 3 & 6 & 0 & 4 & 27 \\
\hline 7 & 0 & 2 & 5 & 4 & 0 & 3 & 5 & 3 & 0 & 5 & 27 \\
\hline 8 & 0 & 1 & 1 & 1 & 2 & 0 & 0 & 1 & 4 & 5 & 15 \\
\hline 9 & 0 & 1 & 0 & 1 & 0 & 1 & 1 & 1 & 1 & 0 & 6 \\
\hline always & 3 & 5 & 3 & 1 & 3 & 2 & 2 & 1 & 2 & 0 & 22 \\
\hline Total & 136 & 192 & 129 & 176 & 128 & 123 & 108 & 106 & 138 & 147 & 1383 \\
\hline
\end{tabular}

${ }^{a}$ Do you justify: Cheating on tax (1-never, 10-always). Source: own computations.

\section{References}

1. Lachapelle, E.; Bergeron, T.; Nadeau, R.; Daoust, J.F.; Dassonneville, R.; Bélanger, É. Citizens' Willingness to Support New Taxes for COVID-19 Measures and the Role of Trust. Politics Policy 2021, 49, 534-565. [CrossRef]

2. Harman, O.; Jensen, A.D.; Naeem, F.; Saab, M.; Wani, S.; Wilkinson, N. COVID-19 and taxes: Policies for the post-pandemic recovery. Int. Growth Cent. 2021, 1-20. Available online: https://ideas.repec.org/p/ehl/lserod/108666.html (accessed on 19 August 2020).

3. Michel, A.N. Post-COVID-19 Tax Policy: Keeping Taxes Low to Ensure a Robust Recovery. Herit. Found. Backgr. 2020, $3549,1-13$.

4. Waris, A. Solidarity Taxes in the Context of Economic Recovery Following the COVID-19 Pandemic. NYU Center Int. Coop. 2021, 1-37. Available online: https:/ / cic.nyu.edu/publications/solidarity-taxes-context-economic-recovery-following-covid-19 -pandemic (accessed on 9 August 2021).

5. Desilver, D. High-Income Americans Pay Most Income Taxes, but Enough to Be 'Fair'? PewResearch Center. Available online: http: //www.pewresearch.org/fact-tank/2016/04/13/high-incomeamericans-pay-most-income-taxes-but-enough-to-be-fair/ (accessed on 19 August 2020).

6. Bundeszentrale fur Deutsche Bildung. Die Soziale Situation in Deutschland. Einkommenssteueranteile. [The Social Situation in Germany. Income Tax Contributions.]. Available online: http:/ / www.bpb.de/nachschlagen/zahlen-und-fakten/soziale-situationindeutschland/61772/ einkommensteueranteile (accessed on 19 August 2020).

7. Stiglitz, J.E. Improving the Distribution of Wealth: Lecture in Memory of Anthony Atkinson. Available online: https:// academiccommons.columbia.edu/doi/10.7916/d8-venb-vk09/download (accessed on 11 June 2020).

8. Stiglitz, J.E. Joseph Stiglitz: The Price of Inequality / The New School. Available online: https://www.youtube.com/watch?v= rVFetg5OPN8 (accessed on 19 August 2020).

9. Stiglitz, J.E. The Price of Inequality: How Today's Divided Society Endangers our Future; WW Norton and Company: New York, NY, USA, 2012.

10. Gangl, K.; Torgler, B. How to Achieve Tax Compliance by the Wealthy: A Review of the Literature and Agenda for Policy. Soc. Issues Policy Rev. 2020, 14, 108-151. [CrossRef]

11. Bregman, R. Utopia for Realists: And How We Can Get There; Bloomsbury: London, UK, 2017.

12. Piketty, T. Capital in the 21st Century; Presi dent and Fellows, Harvard College: Cambridge, MA, USA, 2013.

13. Allingham, M.G.; Sandmo, A. Income tax evasion: A theoretical analysis. J. Public Econ. 1972, 1, 323-338. [CrossRef]

14. Hofmann, E.; Voracek, M.; Bock, C.; Kirchler, E. Tax compliance across sociodemographic categories: Meta-analyses of survey studies in 111 countries. J. Econ. Psychol. 2017, 62, 63-71. [CrossRef]

15. Ahmed, E.; Braithwaite, V. When tax collectors become collectors for child support and student loans: Jeopardizing the revenue base? Kyklos 2004, 57, 303-326. [CrossRef]

16. Chung, J.; Trivedi, V.U. The effect of friendly persuasion and gender on tax compliance behavior. J. Bus. Ethics 2003, 47, 133-145. [CrossRef]

17. Slemrod, J. An empirical test for tax evasion. Rev. Econ. Stat. 1985, 67, 232-238. [CrossRef]

18. Ali, M.M.; Cecil, H.W.; Knoblett, J.A. The effects of tax rates and enforcement policies on taxpayer compliance: A study of self-employed taxpayers. Atl. Econ. J. 2001, 29, 186-202. [CrossRef]

19. Weck-Hannemann, H.; Pommerehne, W. Einkommenssteuerhinterziehung in der Schweiz: Eine empirische Analyse. J. Econ. Stat. 1989, 125, 517-556.

20. Lang, O.; Nöhrbaß, K.-H.; Stahl, K. On income tax avoidance: The case of Germany. J. Public Econ. 1997, 66, 327-347. [CrossRef]

21. Baldry, J.C. Income tax evasion and the tax schedule: Some experimental results. Public Financ. 1987, 42, 347-383. 
22. Anderhub, V.; Giese, S.; Güth, W.; Hoffmann, A.; Otto, T. Tax evasion with earned income-An experimental study. Finanz Arch. 2001, 58, 188-206.

23. Collins, J.H.; Plumlee, R.D. The taxpayers labor and reporting decision-The effect of audit schemes. Account. Rev. 1991, $66,559-576$.

24. Christian, C.W. Voluntary Compliance with the Individual Income Tax: Results from the 1988 TCMP Study. In The IRS Research Bulletin; The United States Department of the Treasury: Washington, DC, USA, 1994; pp. 35-42.

25. Fishlow, A.; Friedman, J. Tax Evasion, inflation and stabilization. J. Dev. Econ. 1994, 43, 105-123. [CrossRef]

26. Alm, J.; Jackson, B.R.; McKee, M. Estimating the determinants of taxpayer compliance with experimental data. Natl. Tax J. 1992, 45, 107-114. [CrossRef]

27. Yaniv, G. The tax compliance demand curve: A diagrammatical approach to income tax evasion. J. Econ. Educ. 2009, 40, 213-224. [CrossRef]

28. Feinstein, J. An economometric analysis of income tax evasion and its detection. RAND J. Econ. 1991, 22, 14-35. [CrossRef]

29. Park, C.G.; Hyun, J.K. Examining the determinants of tax compliance by experimental data: A case of Korea. J. Policy Modeling 2003, 25, 673-684. [CrossRef]

30. Porcano, T.M. Correlates of tax evasion. J. Econ. Psychol. 1988, 9, 47-67. [CrossRef]

31. Wärneryd, K.; Walerud, B. Taxes and economic behaviour: Some interview data on tax evasion in Sweden. J. Econ. Psychol. 1982, 2, 187-211. [CrossRef]

32. Wenzel, M. Misperceptions of social norms about tax compliance: From theory to intervention. J. Econ. Psychol. 2005, 26, 862-883. [CrossRef]

33. Mols, F.; Jetten, J. The Wealth Paradox. Economic Prosperity and the Hardening of Attitudes; Cambridge University Press: Cambridge, UK, 2017.

34. Jetten, J. The wealth paradox: Prosperity and opposition to immigration. Eur. J. Soc. Psychol. 2019, 49, 1097-1113. [CrossRef]

35. Piff, P.K.; Kraus, M.W.; Côté, S.; Cheng, B.H.; Keltner, D. Having less, giving more: The influence of social class on prosocial behavior. J. Personal. Soc. Psychol. 2010, 99, 771-784. [CrossRef]

36. Magee, J.C.; Galinsky, A.D. Social hierarchy: The self-reinforcing nature of power and status. Acad. Manag. Ann. 2008, 2, 351-398. [CrossRef]

37. Fisman, R.; Jakiela, P.; Kariv, S.; Markovits, D. The distributional preferences of an elite. Science 2015, 349. [CrossRef]

38. Cardel, M.I.; Johnson, S.L.; Beck, J.; Dhurandhard, E.; Keita, A.D.; Tomczik, A.C.; Allison, D.B. The effects of experimentally manipulated social class on acute eating behaviour. A randomized, crossover pilot study. Physiol. Behav. 2016, 162, 93-101. [CrossRef]

39. Piff, P.K.; Stancato, D.M.; Coté, S.; Mendoza-Denton, R.; Keltner, D. Higher social class predicts increases unethical behavior. Proc. Natl. Acad. Sci. USA 2012, 109, 4086-4091. [CrossRef]

40. Stellar, J.E.; Manzo, V.M.; Kraus, M.W.; Keltner, D. Class and compassion: Socioeconomic factors predict responses to suffering. Emotion 2012, 12, 449-459. [CrossRef]

41. Andreoni, J.; Nikiforakis, N.; Stoop, J. Are the rich more selfish than the poor, or do they just have more money? A natural field experiment. Natl. Bur. Econ. Res. 2017, 1-29. [CrossRef]

42. Balakrishnan, A.; Palma, P.A.; Patenaude, J.; Campbell, L. A 4-study replication of the moderating effects of greed on socioeconomic status and unethical behaviour. Sci. Data 2017, 4, 1-7. [CrossRef] [PubMed]

43. Leckelt, M.; Richter, D.; Schröder, C.; Küfner, A.C.P.; Grabka, M.M.; Back, M.D. The rich are different: Unravelling the perceived and self-reported personality profiles of high-net-worth individuals. Br. J. Psychol. 2019, 110, 769-789. [CrossRef] [PubMed]

44. Manstead, A.S.R. The psychology of social class: How socioeconomic status impact thought, feelings and behaviour. Br. J. Soc. Psychol. 2018, 57, 267-291. [CrossRef] [PubMed]

45. Brehm, J.W. A Theory of Psychological Reactance; Academic Press: Oxford, UK, 1966.

46. Cherry, T.L.; Kroll, S.; Shogren, J.F. The impact of endowment heterogeneity and origin on public good contributions: Evidence from the lab. J. Econ. Behav. Organ. 2005, 57, 357-365. [CrossRef]

47. Frey, B.S.; Torgler, B. Tax morale and conditional cooperation. J. Comp. Econ. 2007, 35, 136-159. [CrossRef]

48. Fung JM, Y.; Au, W. Effect of inequality on cooperation: Heterogeneity and hegemony in public goods dilemma. Organ. Behav. Hum. Decis. Process. 2014, 123, 9-22. [CrossRef]

49. Reuben, E.; Riedl, A. Enforcement of contribution norms in public good games with heterogeneous populations. Games Econ. Behav. 2013, 77, 122-137. [CrossRef]

50. De Cremer, D.; van Dijk, E. Perceived criticality and contribution in public good dilemmas: A matter of feeling responsible to all? Group Process. Intergroup Relat. 2002, 5, 319-332. [CrossRef]

51. Brown-Iannuzzi, J.L.; Dotsch, R.; Cooley, E.; Payne, B.K. The relationship between mental representations of welfare recipients and attitudes toward welfare. Psychol. Sci. 2017, 28, 92-103. [CrossRef] [PubMed]

52. Neudorfer, N.S. Commodities and corruption-How the middle class and democratic institutions lead to less corruption in resource-rich countries. Resour. Policy 2018, 58, 175-191. [CrossRef]

53. Loayza, N.; Rigolini, J.; Llorente, G. Do middle classes bring institutional reforms? The World Bank. Policy Research Working paper. Econ. Lett. 2012, 116, 440-444. [CrossRef] 
54. Banerjee, A.V.; Duflo, E. What is middle class about the middle classes around the world? J. Econ. Perspect. 2008, $22,3-28$. [CrossRef] [PubMed]

55. Center for Global Development, Working Paper 207. The (Indispensable) Middle Class in Developing Countries; or, the Rich and the Rest, not the Poor and the Rest. Available online: https:/ /www.cgdev.org/sites /default/files/1423994_file_Birdsall_ Indispensable_Middle_FINAL.pdf (accessed on 10 August 2021).

56. Cox, D. Raising revenue in the underground economy. Natl. Tax J. 1984, 37, 283-288. [CrossRef] 